\title{
Role of Remittances on Gross Domestic Product (GDP) Growth in Developing Countries: The Case of Bangladesh
}

\author{
Md. Shahadat Hossain*, Lee Chin, Rusmawati Said and Suryati Binti Ishak \\ Department of Economics, School of Business and Economics, Universiti Putra Malaysia, Malaysia
}

\begin{abstract}
Bangladesh is one of the top ten remittance recipient countries and the contribution of remittance to the GDP has increased dramatically in recent years. This study examines the role of remittances on GDP growth in Bangladesh and Time series data for decades from 1996 to 2019 extracted from the World Bank database as well as Bangladesh Bank statistics were used. The study was conducted being motivated from conflicting results that have emerged in the literature on the impact of remittance on the economic growth of different countries. Using ordinary least squares (OLS) and Pearson correlation method, the empirical results of the study have been consistent with some previous studies while also contrasted to some literature on the impact of remittances on GDP, Gross Domestic Savings and Domestic Expenditure of a country. We have found that the remittances have a significant impact on the growth of GDP as well as Gross Domestic Savings and Domestic Expenditure. Since, there are no recent studies on the role of remittances on GDP, therefore, the findings of the study provide a significant insights for policymakers for strengthening policies and regulations relating to harnessing remittances for economic growth. Implications of the study have been discussed.
\end{abstract}

Keywords: Remittances, Economic Growth, Development Level, Bangladesh.

\section{INTRODUCTION}

Bangladesh is one of the top three countries in terms of Gross Domestic Product (GDP) growth in the world (Rooney, 2019). The country has been a significant industrial hub for material products in the ready-made garments industry, which is the secondlargest in the world just behind China. Other industries, such as agricultural, shipbuilding, energy, information and technology and tourism, are also contributing to the economy of the country tremendously (Robinson, 2018). Therefore, the country has retained its level of economic growth over the last few decades and has done so despite the country going through the biggest financial recession which started in 2007 (Metropolitan Chamber of Commerce and Industry, 2020).

Furthermore, foreign direct investment (FDI) has been increasing in recent years due to infrastructure development and a stable government let by present ruling party in Bangladesh that is also similar in other countries where good governance i.e. stable government contribute to the economic growth (Hasina, 2019; Alshammari, Alshuwaiee, \& Aleissa, 2019). Therefore, some industries are recruiting many local available employees, who are cheaper to retain than in other countries (Fan, 2017). However, the country is criticized in terms of the lack of skilled workers for the organizations due to its huge outflow of workers to western and other countries, particularly in Middle

*Address correspondence to this author at the Department of Economics, School of Business and Economics, Universiti Putra Malaysia, Malaysia;

Tel: (603) 8946 7580; Fax: (603) 8948 6188;

E-mail: gs56790@student.upm.edu.my

JEL Classifications: F24; F43; 011
Eastern countries, to earn better money (Rooney, 2019). Therefore, the contribution of the expatriates to the economy has been questionable to many scholars who have argued that the remittance has some problems, especially concerning the shortage of skilled workers for organizations established by local and foreign investments (Robinson, 2018).

However, Bangladesh is one of the top ten remittance recipient countries and the contribution of remittance to the GDP has increased dramatically in recent years, reaching $\$ 15.54$ billion in 2018 , a jump of $14.79 \%$ from 2017 (Rooney, 2019). In this regard, the contribution of remittance constitutes $12 \%$ of the GDP of Bangladesh. However, with the advancement of technology for outsourcing and other recent working opportunities from the growing industries, it is criticized that dependency on foreign remittance sent by the expatriates should be reduced for the greater development of the industries where skilled workers are less. According to Asian Development Bank, (2019), more than half a million foreign employees are working in different industries in Bangladesh in various technical positions, which cannot be taken by local workers due to a lack of competency. Therefore, many scholars are urging for development of the competency levels of the locals, rather than sending them to another country to earn remittance. However, since the late 1990s, remittance flow to Bangladesh, as with other developing countries, has been more than other main external flows, such as foreign direct investment (FDI) and official development assistance (ODA) (Das \& Chowdhury, 2019). Therefore, since remittance has been a significant source of money for the country, 
academic researchers, as well as different policymakers, have expressed significant interest in understanding the effect of remittance for the growth of GDP.

However, there have been mixed findings highlighting contradictory results regarding whether the remittance on the GDP of a country plays a positive role. In this regard, the literature on macro-remittance shows a positive impact of remittance on investment and also in increasing domestic consumption of the receiving country (Glytsos, 1993; Stahl \& Habib, 1989; Loxley \& Sackey, 2008; Giuliano \& Ruiz-Arranz, 2009). A study conducted by Adams \& Page (2005) presented some positive and negative impacts of remittance that have been presented below:

Moreover, a study conducted by Clemens \& McKenzie (2018) also argued against the positive impact of remittance on the GDP of a country. However, in contrast, a study conducted by Ratha (2017) supported the positive impact of remittance on the growth of an economy by increasing foreign exchange reserves, paying external debt services and using remittance as a cushion against capital flight. Meyer \& Shera (2017) identified remittances as a significant source of income and a new financial phenomenon on the basis of the size of the economic impact on the world. According to the World Bank (2019), global remittance has grown by $10 \%$ to $\$ 689$ billion, including $\$ 528$ billion to developing countries. The World Bank has also forecast that the increase of global remittance in 2019 will be $3.7 \%$ to $\$ 715$ billion, including US $\$ 549$ billion to developing countries (World Bank 2019). Thus, a significant proportion of remittance is going to be earned by Bangladesh as one of the top ten recipients of remittances in the world (World Bank 2019).

Remittance surge has been identified as the major source of money in many countries, rather than the foreign direct investment and official aid driven by immigration between developing and developed countries (Hassan, Chowdhury \& Bhuyan, 2016; McKenzie, 2018). Furthermore, reduced transaction costs and the easy process of sending money due to technologies has also contributed to the increased level of remittance from developed countries (Ratha, 2017). Thus, the increasing trend of remittance in the future will remain significant; however, the question of the impact of remittance on GDP remains contradictory in the case of single countries in recent academic literature (Meyer \& Shera, 2017; Ratha, 2017). In this respect, there is no academic literature in recent years relating to impact of remittance on GDP of Bangladesh to provide updated information either it has positive or negative impact. This question also remains unanswerable in the case of Bangladesh which claims a significant proportion of the world's remittance flow. Therefore, the purpose of this study is to investigate the effect of remittance on the growth of GDP per capita and whether it has a positive or negative effect.

\section{LITERATURE REVIEW}

Bangladesh is one of the most populous countries with the highest number of working people being aged

Table 1: Positive and Negative Impacts of Remittances

\begin{tabular}{|c|c|c|}
\hline & Positive impacts & Negative Impacts \\
\hline Macro-level & $\begin{array}{l}\text { Developing foreign exchange ability for receiving country } \\
\text { Stable and counter-cyclical }\end{array}$ & $\begin{array}{l}\text { Deterioration of trade balance by appreciation of local } \\
\text { currency and stimulation of import } \\
\text { Deterioration of social balance } \\
\text { High skilled workers go to developed countries } \\
\text { High economic dependency on remittance }\end{array}$ \\
\hline $\begin{array}{c}\text { In-terms of } \\
\text { household level }\end{array}$ & $\begin{array}{l}\text { Allow family to meet basic needs } \\
\text { Opening up of opportunities for investing in children's } \\
\text { education, health care, etc. } \\
\text { Loosening of constraints in family budget to invest in } \\
\text { business or savings } \\
\text { Emergency resources } \\
\text { Social security resource base }\end{array}$ & $\begin{array}{l}\text { Reduction on local workplaces to be employed. } \\
\text { Rare use of remittance in productive investment }\end{array}$ \\
\hline $\begin{array}{l}\text { Regional and } \\
\text { community level }\end{array}$ & $\begin{array}{l}\text { Developing local economy } \\
\text { Boost local economy } \\
\text { Financing in projects for local development }\end{array}$ & $\begin{array}{l}\text { Significant inequality between family members } \\
\text { High inflation }\end{array}$ \\
\hline
\end{tabular}

Source: Adams \& Page (2005). 
between 25 and 54 years old, being about $39.73 \%$; therefore, it has a significant opportunity to use these people inside and outside of the country for greater economic development (Liton \& Molla, 2017; Indexmundi, 2018). However, a significant proportion of working aged people in Bangladesh are unemployed, either intentionally or unemotionally (Liton \& Molla, 2017). Amongst them are a significant number of people who travel to emerging or developed countries, such as Malaysia, Saudi Arabia, Japan, Korea, Europe, Canada, Australia and the USA, to earn money. As a result, often many people do not return to Bangladesh, which is another significant loss for a country like Bangladesh (International Organisation for Migration, 2014).

However, the remittances sent by the expatriates are used in five main categories being repayment of loans, the purchase of land, food and clothing, home construction and savings (International Organisation for Migration, 2014). Njangang, Noubissi \& Nkengfack (2018) found a positive impact of remittance on the local economy of the recipient countries because it increases the size of their local economy. This finding is also supported from the study of Adams \& Page (2005). Furthermore, Siddique, Shehzadi, Manzoor \& Majeed (2016) also found remittance a significant contribution on the proportion of GDP and poverty alleviation. Remittance significantly increases the local buying power and also consumption levels, which makes a rational positive impact on the multiple levels (Ratha, 2003). This is also supported from contemporary studies where the significant role of remittances has been found in different remittance recipient countries (Adams \& Cuecuecha, 2013; Abadi, Techane, Tesfay, Maxwell \& Vaitla, 2018; Kumar, 2019). Furthermore, Arif Raza, Friemann \& Suleman (2019) and Sultonov, (2016) argued that remittance has a significant influence on higher education in recipient countries. Arif et al. (2019) also found that money sent by the expatriates was spent on the education of their children and other family members who contribute to the long-running development of the overall economy.

Furthermore, remittance creates a base for financial markets and monetary policy developments in the emerging countries to formulate policies and implement them on time (Giuliano \& Ruiz-Arranz, 2009). Giuliano \& Ruiz-Arranz (2009) argued that remittance develops credit constraints on the lower income groups of people whilst facilitating the allocation of capital and creates substitutes for the lack of financial development in many regios (Arkhipova, \& Kulikova,. 2020). Thus, the economic growth of a country is ensured. This is further supported from the study of Fayissa \& Nsiah (2010) and (2013) who also established a significant relationship between remittance and the economic growth of the sixty-four countries in their academic research.

However, remittance receipts by families can reduce participation of the labour force and can also harm the tradeable goods sector by appreciating real exchange rates (Amuedo-Dorantes \& Pozo, 2004; Chami et al., 2008; Hassan \& Holmes, 2013). In this respect, Rodrik (2008) argued that real exchange rate over-valuation mainly undermines the economic growth in the long-run. In this respect, the production of tradeable goods disproportionately suffers due to market failures, as well as institutional weakness (Rodrik, 2008). Furthermore, it is also evident that in the remittance receiving countries, remittances undermine growth and productivity because these are spent on the consumption of foreign goods that are available in the market, rather than investing in productive investments (Lipton, 1980; Brown \& Ahlburg, 1999; Nyasha, 2019). Nyasha (2019) explained that the negative impact of remittances on economic growth can be due to remittances that are channeled towards the consumption of nondurable goods, instead of being directed to the consumption of durable goods and productive economic activities. Barguellil, Zaiem \& Zmami (2013) also found mixed results in their study about the impact of remittances on economic growth. They argued that remittances have both direct and indirect impacts on some remittance recipient countries, but those effects disappear in the case of many other countries. Thus, the effect of remittance on economic growth is contradictory and remittance may lead to the 'Dutch disease' phenomenon in countries where the inflow of remittance creates a real appreciation, or postpones depreciation, of the exchange rates (Chowdhury \& Rabbi, 2014).

\section{METHODOLOGY}

Secondary research methodology was deemed for this study. Therefore, econometric analysis i.e. OLS (ordinary least squares) method was used to estimate the relationship between remittance and the GDP growth of Bangladesh so that the impact of remittance on GDP growth of Bangladesh can be investigated. Therefore, the basic model for analyzing whether remittance impacts on the GDP growth of Bangladesh is: 


$$
y_{\mathrm{t}}=\beta_{0}+\beta_{1} \operatorname{Rem}_{\mathrm{t}}+\beta_{\mathrm{z}} \mathrm{Z}_{\mathrm{t}}+\mathrm{u}_{\mathrm{t}}
$$

In this model, $y$ is the GDP growth while Rem is the remittance and $Z$ is the vector of controls.

In addition, this study also estimated the relationship between remittance and GDP growth as well other variables, such as gross domestic savings and domestic expenditure. It is because remittance is one of the significant economic indicators for Bangladesh which supports in maintaining the balance of domestic expenditure and the gross domestic savings. However, in this respect, this study used the Pearson's correlation coefficient to explore the relationship between remittance and GDP through the formula presented below:

$$
r=\frac{\sum{ }_{i}=-1\left(X_{i}-\bar{X}\right)\left(Y_{i}-\bar{Y}\right)}{\sqrt{\sum^{n} i_{=}{ }_{1}\left(X_{i}-\bar{X}\right)^{2} \sqrt{\sum^{n}{ }_{i}=1}\left(Y_{i}-\bar{Y}\right)^{2}}}
$$

In this respect, the $r$ is the Pearson's correlation coefficient, $X$ is the remittance, $Y$ is GDP, $\bar{X}$ is the mean of $\mathrm{X}$, the $Y$ is the mean of $\mathrm{Y}$, and $\mathrm{i}$ is the numbers of years. It is also significant to mention that the value for the correlation coefficient ranges between -1 (total negative correlation) and +1 (total positive correlation). This is also a similar technique which has been applied to evaluate the relationship between remittance and gross domestic savings expenditure.

\section{RESULTS AND ANALYSIS}

In Table 2 the OLS results show that remittance has an impact on the GDP growth of Bangladesh. It is also similarly identified from the Pearson correlation results which shows the relationship between remittances, GDP growth and other variables. The selected data has been presented in Appendix 1. The results show that remittance can impact on GDP growth as well as the other variables, for example gross domestic savings and also domestic expenditure from 1995 to 2019. It is evidenced from the correlation coefficient result that the difference between remittance and GDP is $0.986^{* *}$. Thus, it shows that the GDP is positive as well as significantly correlated with the remittance sent by the expatriates of Bangladesh. Furthermore, the report shows that the gross domestic savings, as well as the domestic expenditure, in Bangladesh are also positively and significantly correlated with the remittance. Based on these results, it can be argued that remittance has significant influence on the various macroeconomic variables, for example domestic expenditure and gross domestic savings in the case of Bangladesh. The results found in this study have been

\section{Table 2: OLS Results}

\begin{tabular}{|c|c|c|c|c|c|}
\hline Regression & 3 & 729532087.9 & 243177362.6 & 85.38207945 & $1.42015 \mathrm{E}-11$ \\
\hline \multirow[t]{2}{*}{ Total } & 23 & 786494243 & & & \\
\hline & Coefficients & Standard Error & $t$ Stat & $P$-value & Lower 95\% \\
\hline GDP & -0.047069272 & 0.016644297 & -2.827952026 & 0.010393421 & -0.081788667 \\
\hline $\begin{array}{l}\text { Gross Domestic } \\
\text { Savings }\end{array}$ & -0.320775194 & 0.127197387 & -2.52186936 & 0.020263416 & -0.586104294 \\
\hline $\begin{array}{l}\text { Domestic } \\
\text { Expenditure }\end{array}$ & 0.280089635 & 0.050002491 & 5.601513618 & $1.75326 \mathrm{E}-05$ & 0.175786266 \\
\hline
\end{tabular}

\begin{tabular}{|c|c|}
\hline \multicolumn{2}{|c|}{ Regression Statistics } \\
\hline \hline Multiple R & 0.963106747 \\
\hline R Square & 0.927574606 \\
\hline Adjusted R Square & 0.916710797 \\
\hline Standard Error & 1687.633774 \\
\hline Observations & 24 \\
\hline
\end{tabular}


Table 3: Relationship between Remittance and Selected Variables

\begin{tabular}{|c|c|c|c|c|c|}
\hline & Year & Remittance & GDP & Gross Domestic Savings & Domestic Expenditure \\
\hline \hline Year & 1 & & & & \\
\hline Remittance & 0.972015843 & 1 & & & \\
\hline GDP & 0.860119667 & 0.844495766 & 1 & & \\
\hline Gross Domestic Savings & 0.912832975 & 0.90140407 & 0.949933151 & & 1 \\
\hline Domestic Expenditure & 0.928807269 & 0.934395479 & 0.958130967 & 0.989454862 & 1 \\
\hline
\end{tabular}

consistent with some previous studies that have also found that remittance has either a positive impact or a positive or significant relationship with the GDP growth and other variables of a country's economy (Lipton, 1980; Ahlburg, 1991; Brown \& Ahlburg, 1991; Chami et al., 2005).

However, the results of this study are not consistent with the study conducted by Nyasha \& Odhiambo (2019) in the perspective of South Africa, where the remittance is one of the most significant sources of national income, but they found that there was no positive relationship between remittance and GDP growth. However, the use of remittance is one of the significant issues to ensure money is used appropriately to achieve the best results from its use (Das \& Chowdhury, 2019). Therefore, remittance could play different roles in different economies or countries where the governance and systematic government aspects could be different (Das \& Chowdhury, 2019). The results of this study are also found to be similar and consistent with previous similar studies conducted which relate to Bangladesh. In this respect, the results have been found consistent with the findings of Hassan \& Shakur (2017) who have conducted a study on the non-linear effects of remittance on the per-capita GDP. Furthermore, the results of this study are also consistent with the study conducted by Das \& Chowdhury, (2019) on the macroeconomic impact of remittance in Bangladesh. They have also found that remittance has an impact on the economic growth of the economy.

\section{CONCLUSIONS AND IMPLICATIONS}

Overall, the findings of the study reveal that remittances in the case of Bangladesh have a significant impact on the growth of the GDP as well as other variables. However, in this respect, the productive appropriate use or utilization of the remittance has been effective to the continuous economic growth of the country. Our findings have suggested that remittance has been effective for the last two decades in the case of GDP growth but it was negative during the eighties (Mahmud \& Osmani, 1980). In this respect, the effective use of remittance over the last two decades, during a time when Bangladesh experienced technological and infrastructural development, is associated with the fact that the growth of the GDP is the fastest process in South Asia.

The findings of the study would be effective for policymakers with a better understanding about the impact of remittance on the GDP, as well as awareness regarding the efficient usage of the remittance for the growth of GDP. In this respect, the government of Bangladesh can promote the investment processes from remittance as well as improve the policies surrounding remittance to increase the inflow from expatriates. Although the government of Bangladesh has already identified and realized that remittance is a significant source of funding for various projects, the marginal use of remittance by the families is still not very productive in being used in household functions (Das \& Chowdhury, 2019). Therefore, this study suggests that the country should formulate policies for the proper use of remittances as well as the manpower exporting policies. As a result, the manpower skills and their demand in the developed countries in good jobs would be increased and they could send much more money into the country. In addition, Bangladesh could also create strong bilateral relationships with the countries where many expatriates are working and from where they are sending a significant amount of money. Moreover, the country should increase the bargaining power with the countries where the manpower is being sent to work so that those countries can arrange secure and safe workplaces as well as offering dignity in their actions.

\section{RESEARCH LIMITATIONS AND FUTURE DIRECTION}

Like many other research papers, this study has also some limitations that also warrant attention when 
Appendix 1: Remittance and some Macroeconomic Variables of Bangladesh from 1996-2019

\begin{tabular}{|c|c|c|c|c|}
\hline Years & $\begin{array}{l}\text { Remittance } \\
\text { (Million US\$) }\end{array}$ & $\begin{array}{c}\text { GDP } \\
\text { (Million US\$) }\end{array}$ & $\begin{array}{c}\text { Gross Domestic Savings } \\
\text { (Million US\$) }\end{array}$ & $\begin{array}{c}\text { Domestic Expenditure } \\
\text { (Million US\$) }\end{array}$ \\
\hline 1996 & 1217 & 55328 & 6532 & 36618 \\
\hline 1997 & 1475 & 57812 & 7975 & 37610 \\
\hline 1998 & 1525 & 60805 & 8875 & 38108 \\
\hline 1999 & 1706 & 63645 & 9152 & 39085 \\
\hline 2001 & 1882 & 70416 & 10177 & 40236 \\
\hline 2002 & 2501 & 73115 & 11051 & 40572 \\
\hline 2003 & 3062 & 76580 & 11962 & 44930 \\
\hline 2004 & 3372 & 80593 & 13299 & 47944 \\
\hline 2008 & 7915 & 103951 & 17317 & 69303 \\
\hline 2009 & 9689 & 109195 & 20489 & 76422 \\
\hline 2010 & 10987 & 115279 & 23623 & 85439 \\
\hline 2011 & 11650 & 128638 & 25527 & 95553 \\
\hline 2012 & 12843 & 133356 & 27304 & 98332 \\
\hline 2013 & 14461 & 149997 & 31751 & 109265 \\
\hline 2014 & 14228 & 172885 & 38109 & 125467 \\
\hline 2015 & 15317 & 195079 & 41891 & 141310 \\
\hline
\end{tabular}

Source: World Bank (2019) and Bangladesh Bank (2019).

interpreting the findings for example the paper does not include impact of the remittances on the microeconomic factors. However, in future researches these limitations could be overcome. Therefore, the further research based on the findings of this study should focus on the growth consequences of reverse flows related to remittances. Furthermore, in future some studies can be conducted relating to the impact of remittance on the education of children of remittance sender. Moreover, it is also proposed that a study that identifies which economic indicator is most influenced by the remittances, what people are doing with the money they receive - they save, consume, or invest the money and how the money impact on their households and their wellbeing in Bangladesh. Finally, this study could be extended for other countries which are the earner of remittance every year.

\section{REFERENCES}

Abadi, N., Techane, A., Tesfay, G., Maxwell, D., \& Vaitla, B. (2018). The impact of remittances on household food security: A micro perspective from Tigray, Ethiopia (No. 2018/40). WIDER Working Paper. https://doi.org/10.35188/UNU-WIDER/2018/482-7

Alshammari, N., Alshuwaiee, W., \& Aleissa, N. (2019). Does "Good" Governance Promote Economic Growth According to Countries' Conditional Income Distribution. Journal of Reviews on Global Economics, 8, 1046-1061. https://doi.org/10.6000/1929-7092.2019.08.91

Adams Jr, R. H., \& Cuecuecha, A. (2013). The impact of remittances on investment and poverty in Ghana. World Development, 50, 24-4. https://doi.org/10.1016/j.worlddev.2013.04.009

Adams Jr, R. H., \& Page, J. (2005). Do international migration and remittances reduce poverty in developing countries?. World development, 33(10), 1645-1669. https://doi.org/10.1016/j.worlddev.2005.05.004

Ahlburg, DA. 1991. Remittances and their Impact: A Study of Tonga and Western Samoa. Pacific Policy Paper 7, National Centre for Development Studies. 
Arkhipova, L. S., \& Kulikova, E. I. (2020). Assessment of Regional Economic Security Level in Innovative Development. Journal of Reviews on Global Economics, 9, 109-116. https://doi.org/10.6000/1929-7092.2020.09.11

Arif, I., Raza, S. A., Friemann, A., \& Suleman, M. T. (2019). The Role of Remittances in the Development of Higher Education: Evidence from Top Remittance Receiving Countries. Social Indicators Research, 141(3), 1233-1243. https://doi.org/10.1007/s11205-018-1857-8

Asian Development Bank, (2019) Bangladesh Looking Beyond Garments Employment Diagnostic Study. Available at: https://www.adb.org/sites/default/files/publication/190589/ban -beyond-garments-eds.pdf (Accessed January 20, 2020)

Barguellil, A., Zaiem, M. H., \& Zmami, M. (2013). Remittances, education and economic growth a panel data analysis. Journal of Business Studies Quarterly, 4(3), 129.

Brown, R. P., \& Ahlburg, D. A. (1999). Remittances in the south pacific. International Journal of Social Economics, 26(1/2/3), 325-344. https://doi.org/10.1108/03068299910229721

Chami, R. Fullenkamp, C. and Jahjah, S. (2005). Are Immigrant Remittance Flows a Source of Capital for Development? IMF Economic Review, 52(1), 55-81.

Chowdhury, M. B., \& Rabbi, F. (2014). Workers' remittances and Dutch disease in Bangladesh. The Journal of International Trade \& Economic Development, 23(4), 455-475. https://doi.org/10.1080/09638199.2012.738240

Das, A., \& Chowdhury, M. Macroeconomic impacts of remittances in Bangladesh: The role of reverse flows. Economic Notes: Review of Banking, Finance and Monetary Economics. 48(3), $1-19$ https://doi.org/10.1111/ecno.12139

Fan, Q. (2017) What can Bangladesh do to deliver more and better jobs for everyone? Available at: https://blogs.worldbank.org/endpovertyinsouthasia/what-canbangladesh-do-deliver-more-and-better-jobs-everyone (Accessed on 21 December 2019)

Fayissa, B., \& Nsiah, C. (2010). The impact of remittances on economic growth and development in Africa. The American Economist, 55(2), 92-103. https://doi.org/10.1177/056943451005500210

Giuliano, P., \& Ruiz-Arranz, M. (2009). Remittances, financial development, and growth. Journal of Development Economics, 90(1), 144-152. https://doi.org/10.1016/j.jdeveco.2008.10.005

Hasina, S., (2019) Bangladesh is booming - and here's why, says the Prime Minister. Available at: https://www.weforum.org/ agenda/2019/10/bangladesh-is-booming/ (Accessed January 11, 2020)

Hassan, G. M., Chowdhury, M., \& Bhuyan, M. (2016). Growth Effects of Remittances in Bangladesh: Is there a U-shaped Relationship?. International Migration, 54(5), 105-121. https://doi.org/10.1111/imig.12242
Hassan, G., \& Shakur, S. (2017). Nonlinear effects of remittances on per capita GDP growth in Bangladesh. Economies, 5(3), 25. https://doi.org/10.3390/economies5030025

International Organisation for Migration, (2014) Gender and Migration from Bangladesh. Available at: https://www.iom.int/countries/ bangladesh (Accessed November 22, 2019)

Indexmundi, (2018) Bangladesh's population Age structure. Available at: https://www.indexmundi.com/bangladesh/age structure. html_(Accessed August 22, 2019)

Kumar, B. (2019). The impact of international remittances on poverty alleviation in Bangladesh. Remittances Review, 4(1), 67-86. https://doi.org/10.33182/rr.v4i1.665

Lipton, M. (1980). Migration from rural areas of poor countries: the impact on rural productivity and income distribution. World development, 8(1), 1-24. https://doi.org/10.1016/0305-750X(80)90047-9

Metropolitan Chamber of Commerce and Industry, (2020) BANGLADESH ECONOMY DURING 2008-2009. Available at: www.mccibd.org/pages/bangladesh-economy-during2008-2009.php (Accessed on 21 March 2020)

Meyer, D., \& Shera, A. (2017). The impact of remittances on economic growth: An econometric model. Economia, 18(2), 147-155. https://doi.org/10.1016/j.econ.2016.06.001

Njangang, H., Noubissi, E., \& Nkengfack, H. (2018). Do remittances increase the size of the informal economy in Sub-saharan African countries?. Economics Bulletin, 38(4), 1997-2007.

Nsiah, C., \& Fayissa, B. (2013). Remittances and economic growth in Africa, Asia, and Latin American-Caribbean countries: a panel unit root and panel cointegration analysis. Journal of Economics and Finance, 37(3), 424-441. https://doi.org/10.1007/s12197-011-9195-6

Nyasha, S. (2019). Remittances and economic growth: Empirical evidence from South Africa. Working Paper. UNISA Economic Research Working Papers. 108.

Robinson, G., (2018) The rise and rise of Bangladesh https://asia.nikkei.com/Spotlight/Cover-Story/The-rise-andrise-of-Bangladesh

Rodrik, D. (2008). The real exchange rate and economic growth. Brookings papers on economic activity, 2008(2), 365-412. https://doi.org/10.1353/eca.0.0020

Rooney, K. (2019) Here's what you need to know about Bangladesh's rocketing economy. Available at: https://www.weforum.org/agenda/2019/11/bangladesh-gdpeconomy-asia/ (Accessed December 14, 2019)

Siddique, H. M. A., Shehzadi, I., Manzoor, M. R., \& Majeed, M. T. (2016). Do international migration and remittances reduce poverty in developing countries? Science International Lahore 28(2) 1519-1524.

Sultonov, M. (2016). The Russian financial crisis and workers' remittances to Tajikistan and the Kyrgyz Republic. Journal of Reviews on Global Economics, 5, 344-353. https://doi.org/10.6000/1929-7092.2016.05.29

\section{DOI: https://doi.org/10.6000/1929-7092.2020.09.23}

(c) 2020 Hossain et al.; Licensee Lifescience Global.

This is an open access article licensed under the terms of the Creative Commons Attribution Non-Commercial License (http://creativecommons.org/licenses/by-nc/3.0/) which permits unrestricted, non-commercial use, distribution and reproduction in any medium, provided the work is properly cited. 